\title{
Pittosporum deplanchei
}

\author{
Assessment by: Gemmill, C., Veillon, J.-M., Amice, R., Cazé, H., Dumontet, V., \\ Fleurot, D., Garnier, D., Gâteblé, G. \& Maggia, L.
}

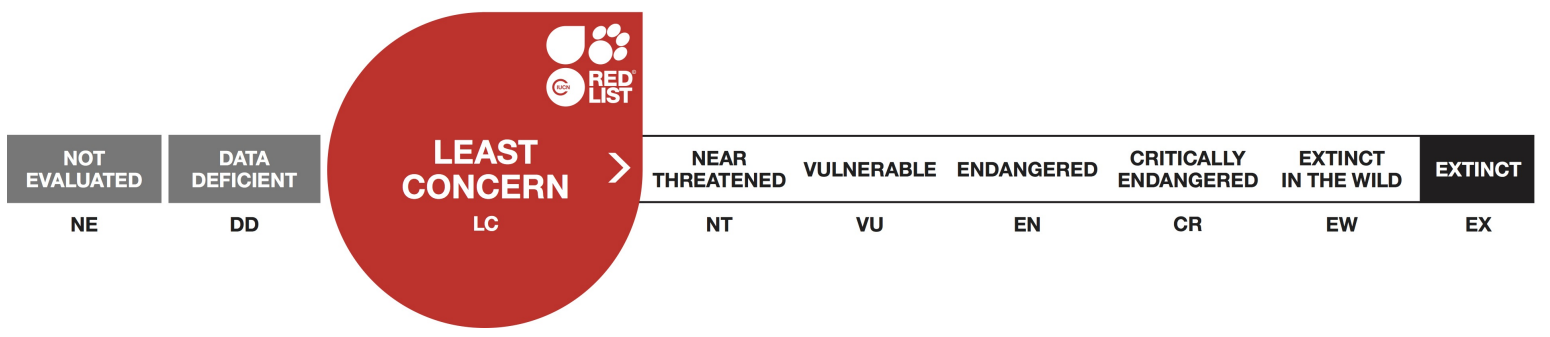

View on www.iucnredlist.org

Citation: Gemmill, C., Veillon, J.-M., Amice, R., Cazé, H., Dumontet, V., Fleurot, D., Garnier, D., Gâteblé, G. \& Maggia, L. 2017. Pittosporum deplanchei. The IUCN Red List of Threatened Species 2017: e.T82947198A82951782. http://dx.doi.org/10.2305/IUCN.UK.20173.RLTS.T82947198A82951782.en

Copyright: ( 2017 International Union for Conservation of Nature and Natural Resources Reproduction of this publication for educational or other non-commercial purposes is authorized without prior written permission from the copyright holder provided the source is fully acknowledged.

Reproduction of this publication for resale, reposting or other commercial purposes is prohibited without prior written permission from the copyright holder. For further details see Terms of Use.

The IUCN Red List of Threatened Species ${ }^{T M}$ is produced and managed by the IUCN Global Species Programme, the IUCN Species Survival Commission (SSC) and The IUCN Red List Partnership. The IUCN Red List Partners are: Arizona State University; BirdLife International; Botanic Gardens Conservation International; Conservation International; NatureServe; Royal Botanic Gardens, Kew; Sapienza University of Rome; Texas A\&M University; and Zoological Society of London. 


\section{Taxonomy}

\begin{tabular}{|c|c|c|c|c|}
\hline Kingdom & Phylum & Class & Order & Family \\
\hline Plantae & Tracheophyta & Magnoliopsida & Rosales & Pittosporaceae \\
\hline
\end{tabular}

Taxon Name: Pittosporum deplanchei Brongn. \& Gris

\section{Taxonomic Source(s):}

Tirel, Ch. and Veillon, J.-M. 2002. Flore de la Nouvelle-Calédonie, tome 24. Pittosporaceae. Museum d'Histoire Naturelle, Paris.

\section{Assessment Information}

Red List Category \& Criteria: Least Concern ver 3.1

Year Published: 2017

Date Assessed: July 23, 2015

\section{Justification:}

Pittosporum deplanchei is an endemic small tree of New Caledonia. It is quite common and abundant on the southern part of Grande Terre, and is also found on the north part on Mé Maoya and Koniambo foothills, even on Mount Tchingou. With an area of occurrence equal to 7,640 $\mathrm{km}^{2}$ and an area of occupation of $240 \mathrm{~km}^{2}$ and no major threats, P. deplanchei is assessed as Least Concern (LC).

\section{Geographic Range}

\section{Range Description:}

Pittosporum deplanchei is a common and abundant endemic small tree of New Caledonia that is distributed on the southern part of Grande Terre, which is also found on the north part on Mé Maoya and Koniambo foothills, even on Mount Tchingou.

\section{Country Occurrence:}

Native: New Caledonia 


\section{Distribution Map}

\section{Pittosporum deplanchei}
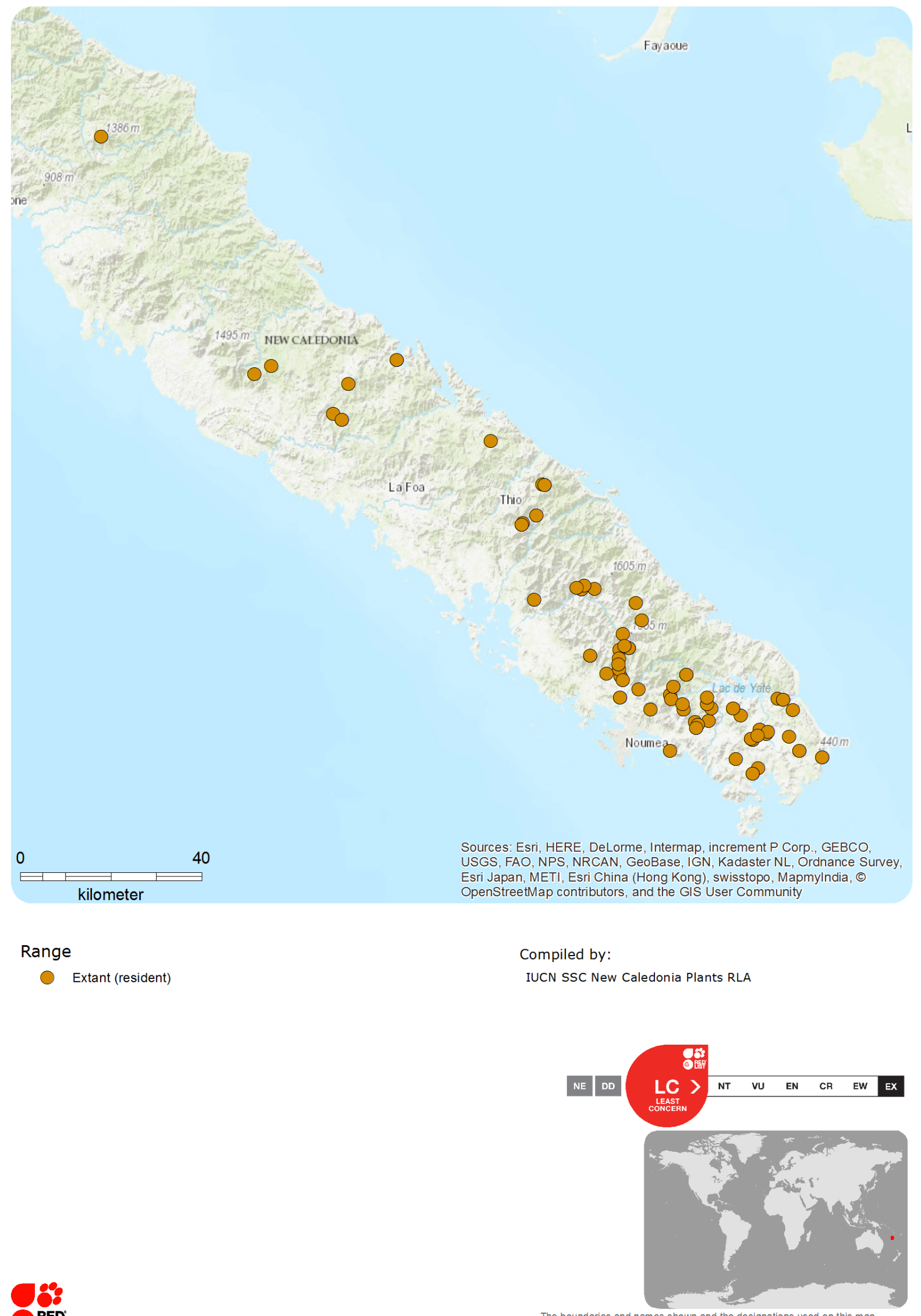


\section{Population}

Population size is not known precisely, but it is distributed over the entire southern part of Grande Terre.

Current Population Trend: Stable

\section{Habitat and Ecology (see Appendix for additional information)}

Pittosporum deplanchei is found in dense humid forest, on forest edges but also in shrubland on ultramafic substrates at an altitudinal range $100-1,350 \mathrm{~m}$ asl.

Systems: Terrestrial

\section{Threats}

Pittosporum deplanchei does not appear affected by any threat specifically.

\section{Conservation Actions (see Appendix for additional information)}

Pittosporum deplanchei is not protected by legislation but occurs in several protected areas: réserve naturelle du Massif du Kouakoué, réserve intégrale de la Montagne des Sources, réserve naturelle du Mont Mou, Parc Provincial de la Rivière Bleue, aire de gestion durable des ressources des Bois du Sud, réserve naturelle de la Forêt Cachée, réserve naturelle de la forêt de Saille, réserve naturelle de la Haute Dumbéa, réserve naturelle du barrage de Yaté, réserve naturelle du Pic du Pin, and réserve naturelle des Chutes de la Madeleine.

\section{Credits}

Assessor(s): $\quad$ Gemmill, C., Veillon, J.-M., Amice, R., Cazé, H., Dumontet, V., Fleurot, D., Garnier, D., Gâteblé, G. \& Maggia, L.

Reviewer(s): $\quad$ Tanguy, V.

Facilitators(s) and Chanfreau, S.

Compiler(s): 


\section{Bibliography}

Endemia.nc. 2016. Faune et Flore de Nouvelle-Calédonie. Available at: http://www.endemia.nc.

IUCN. 2017. The IUCN Red List of Threatened Species. Version 2017-3. Available at: www.iucnredlist.org. (Accessed: 7 December 2017).

Tirel, Ch. and Veillon, J.-M. 2002. Flore de la Nouvelle-Calédonie, tome 24. Pittosporaceae. Museum d'Histoire Naturelle, Paris.

\section{Citation}

Gemmill, C., Veillon, J.-M., Amice, R., Cazé, H., Dumontet, V., Fleurot, D., Garnier, D., Gâteblé, G. \& Maggia, L. 2017. Pittosporum deplanchei. The IUCN Red List of Threatened Species 2017: e.T82947198A82951782. http://dx.doi.org/10.2305/IUCN.UK.2017-3.RLTS.T82947198A82951782.en

\section{Disclaimer}

To make use of this information, please check the Terms of Use.

\section{External Resources}

For Images and External Links to Additional Information, please see the Red List website. 


\section{Appendix}

\section{Habitats}

(http://www.iucnredlist.org/technical-documents/classification-schemes)

\begin{tabular}{|c|c|c|c|}
\hline Habitat & Season & Suitability & $\begin{array}{l}\text { Major } \\
\text { Importance? }\end{array}$ \\
\hline 1. Forest -> 1.6. Forest - Subtropical/Tropical Moist Lowland & - & Suitable & - \\
\hline 1. Forest -> 1.9. Forest - Subtropical/Tropical Moist Montane & - & Suitable & - \\
\hline 3. Shrubland -> 3.5. Shrubland - Subtropical/Tropical Dry & - & Suitable & - \\
\hline 3. Shrubland -> 3.7. Shrubland - Subtropical/Tropical High Altitude & - & Suitable & - \\
\hline
\end{tabular}

\section{Conservation Actions in Place}

(http://www.iucnredlist.org/technical-documents/classification-schemes)

\begin{tabular}{|l|}
\hline Conservation Actions in Place \\
\hline In-Place Land/Water Protection and Management \\
\hline Occur in at least one PA: Yes \\
\hline Invasive species control or prevention: No \\
\hline In-Place Species Management \\
\hline Successfully reintroduced or introduced beningly: No \\
\hline Subject to ex-situ conservation: No \\
\hline
\end{tabular}

\section{Additional Data Fields}

\begin{tabular}{|l|}
\hline Distribution \\
\hline Estimated area of occupancy (AOO) $\left(\mathrm{km}^{2}\right): 240$ \\
\hline Continuing decline in area of occupancy (AOO): No \\
\hline Extreme fluctuations in area of occupancy (AOO): No \\
\hline Estimated extent of occurrence (EOO) (km²): 7640 \\
\hline Continuing decline in extent of occurrence (EOO): No \\
\hline Extreme fluctuations in extent of occurrence (EOO): No \\
\hline Continuing decline in number of locations: No \\
\hline Extreme fluctuations in the number of locations: No \\
\hline Lower elevation limit (m): 100 \\
\hline Upper elevation limit (m): 1350 \\
\hline
\end{tabular}




\section{Population}

Continuing decline of mature individuals: No

Extreme fluctuations: No

Population severely fragmented: No

Extreme fluctuations in subpopulations: No

Habitats and Ecology

Continuing decline in area, extent and/or quality of habitat: No

Generation Length (years): 0 


\section{The IUCN Red List Partnership}

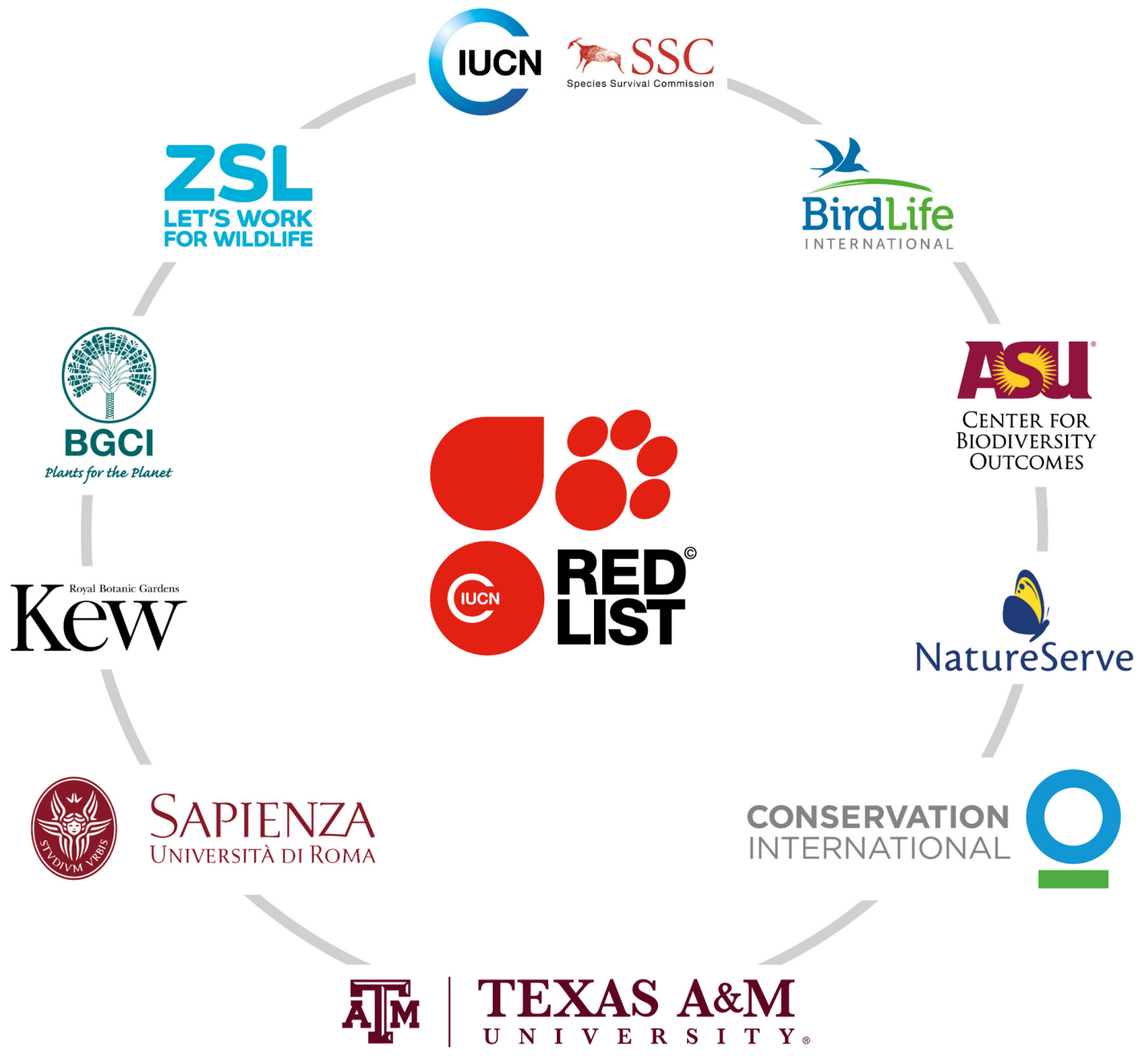

The IUCN Red List of Threatened Species ${ }^{\mathrm{TM}}$ is produced and managed by the IUCN Global Species Programme, the IUCN Species Survival Commission (SSC) and The IUCN Red List Partnership.

The IUCN Red List Partners are: Arizona State University; BirdLife International; Botanic Gardens Conservation International; Conservation International; NatureServe; Royal Botanic Gardens, Kew; Sapienza University of Rome; Texas A\&M University; and Zoological Society of London. 